\title{
How Much Are Borrowers Willing to Pay to Remove Uncertainty Surrounding Mortgage Defaults?
}

\author{
Jackson T. Anderson ${ }^{1} \cdot$ Scott Gibson ${ }^{2} \cdot$ Kimberly F. Luchtenberg $^{3}$ • \\ Michael J. Seiler ${ }^{4}$ ii
}

Accepted: 24 November 2020 / Published online: 3 February 2021

(C) Springer Science+Business Media, LLC, part of Springer Nature 2021

\begin{abstract}
Using a large, non-student sample, we assess and differentiate between borrowers' Risk Aversion and Ambiguity Aversion levels and their willingness to pay to resolve a mortgage default settlement negotiation. Ambiguity Aversion is found to be negatively associated with willingness to pay for borrowers with high financial literacy in both the gain and loss domains, whereas personality traits matter more for borrowers with low financial literacy. This finding is important to policymakers in that they should adopt differential resolution strategies for defaulting borrowers based on these intervening variables.
\end{abstract}

Keywords Ambiguity aversion · Risk aversion · Prospect theory $\cdot$ Experiment $\cdot$ Mortgage default

JEL Classifications G41 · R22

Michael J. Seiler

mjseiler@wm.edu

Jackson T. Anderson

janderson22@cmc.edu

Scott Gibson

Scott.Gibson@mason.wm.edu

Kimberly F. Luchtenberg

luchtenb@american.edu

1 Claremont McKenna College, Claremont, CA 91711, USA

2 College of William and Mary, Raymond A. Mason College of Business, Williamsburg, VA 23187, USA

3 Kogod School of Business, American University, Washington, DC 20016, USA

4 College of William \& Mary, Williamsburg, VA 23187, USA 


\section{Introduction}

When returns are associated with specific probabilistic outcomes, risk aversion describes a person's insistence on requiring additional return when taking on an additional unit of risk. This approach to decision making is appropriate when operating in understood environments with clearly defined outcomes. However, this does not describe real world situations people find themselves in for the first and possibly only time, when even experts are unsure how laws will be applied, and when the actions of other parties are untested and uncertain. In these cases, it is nearly impossible to assign to any reasonable degree the probability of a particular outcome, much less identify the potential outcomes themselves. Instead, these situations can best be described as ambiguous, leading researchers to differentiate between Risk Aversion and Ambiguity Aversion.

The seminal work of Kahneman and Tversky (1979), known as prospect theory, finds that losses hurt roughly twice as much as gains feel good, and as such, people will take reasonable measures to avoid the loss domain. The extant literature has found that people are generally Ambiguity Averse over gains and small losses, and that this is an important region to examine in a world where financial leverage is limited, and investments represent a small portion of an investor's overall wealth. But, this poorly describes the environment surrounding a typical mortgage borrower. Even high quality, conforming loans have a loan-to-value (LTV) ratio of $80 \%$ at origination. And many have an LTV of 0.97 , a leverage ratio unheard of in other areas of finance and economics. Add to this that a home is the largest investment a person will typically ever make, and we can quickly understand that borrower behavior can change when homeowners find themselves substantially underwater (i.e., negative equity) due to sharp home price declines as they did during the 2008 Great Financial Crisis (GFC). When borrowers defaulted during the $2008 \mathrm{GFC}$, the system was ill prepared to handle the crisis, resulting in a level of uncertainty like no other investment. Collectively, the high percentage of a person's overall wealth tied up in a mortgage, the extreme financial leverage used in mortgages, and the high degree of uncertainty surrounding how defaults would be handled, combine to create a unique laboratory to examine Ambiguity Aversion in the loss domain. Golman and Loewenstein (2018) explain that Ambiguity Aversion is context specific. Chen and Chang (2019) examined the role of Ambiguity Aversion in insurers' pricing of mortgage insurance; however, no study has applied Ambiguity Aversion to the extremely uncertain environment of borrower decisions surrounding mortgage defaults. We view this as a unique opportunity to understand decision making in an understudied region of the loss domain - extreme losses.

We employ a large, non-student sample and assess participants' willingness to pay (WTP) to successfully resolve either a risky or an ambiguous mortgage default situation in both the gain and loss domains. To measure Ambiguity Aversion, we employ the multiple price listing instrument developed by Gneezy et al. (2015). We are careful to control for financial history and literacy, factors known to be related to the frequency of mortgage defaults (Harrison et al. 2020). We also include personality traits identified in the psychology literature that explain decision making behaviors. ${ }^{1}$

We find that Ambiguity Aversion is negatively related to the amount participants are willing to pay to resolve the mortgage default proceedings and that Risk Aversion is not

\footnotetext{
${ }^{1}$ See Borghans et al. 2008 for a comprehensive review of personality traits in economics and psychology. Dohmen et al. 2010, Becker et al. 2012, Elabed and Carter 2015, Rustichini et al. 2016 are also relevant.
} 
significantly related to the amount participants are willing to pay in either the gain or loss domains. We also find that participants who are most financially literate and those who have not previously defaulted on a loan tend to have a stronger relation between Ambiguity Aversion and the amount willing to pay to resolve the settlement. The result is consistent with the most Ambiguity Averse engaging in costly efforts to increase literacy, but not the most Risk Averse. The difference highlights the distinction between the measures. Ambiguity inherent in a financial decision is associated with literacy, but the systematic (i.e., nondiversifiable) risk inherent is immutable.

With respect to personality traits, extraverts - regardless of their ambiguity and risk preferences - are willing to pay more to ensure positive outcomes in both the gain and loss domains, but only for participants with low financial literacy. Personality had little influence on the decision of the highly financially literate. This finding that feelings about a subject may influence behaviors controlling for ambiguity and risk preferences highlights the need to conduct further research at the intersection of the economics and psychology literature. That financial literacy may reduce the influence of personality on mortgage default settlement decisions underscores the importance of financial education. Additionally, understanding the role ambiguity plays in mortgage default behavior is critically important to help policymakers manage borrower behavior when facing economic challenges like the GFC or the more recent COVID-19 pandemic.

\section{Literature Review}

Since the seminal work of Ellsberg (1961), ambiguous decisions involving unknown probabilistic payoffs have been distinguished from risky ones involving known probabilistic payoffs. Numerous behavioral studies of ambiguity and risk followed, usually involving participants making a gamble with outcomes that vary the amount of money (or balls in an urn) to be won. The evidence overwhelmingly supports Ellsberg's finding that people dislike ambiguity and will incur significant costs to avoid situations with uncertain payoffs while in the gain domain. The insights of Ambiguity Aversion in the gain domain help explain real-world phenomena such as when investors choose to exercise stock options (Izhakian and Yermack 2017), equity portfolio puzzles including poor portfolio diversification (Bossaerts et al. 2010; Dimmock et al. 2016; Bianchi and Tallon 2018; Peijnenburg 2018), the equity premium puzzle (Maenhout 2004; Collard et al. 2018; Gollier 2011; Ju and Miao 2012), the stock market participation puzzle (Dow and Werlang 1992; Easley and O'Hara 2009), and mortgage insurance premiums (Chen and Chang 2019). Recent research though calls into question Ambiguity Aversion's influence in the loss domain. Kocher et al. (2018) provide experimental evidence of ambiguity attitudes when subjects are presented with different likelihoods of positive and negative payoffs. Subjects, on average, exhibit Ambiguity Aversion behavior for moderate likelihood gain prospects (consistent with Ellsberg 1961), but less is known about Ambiguity Seeking behavior for large likelihood loss prospects.

The subject of Ambiguity Aversion has not received much attention in the real estate literature. The paper closest to ours is Chen and Chang's (2019) study of the effect of insurer's Ambiguity Aversion on the pricing of mortgage insurance. The authors find that Ambiguity Aversion is associated with increases in mortgage insurance premiums, 
an effect that increases with higher LTV. We extend this line of research by investigating Ambiguity Aversion's effect on borrower decisions rather than pricing decisions of the insurer.

\section{Experimental Design}

Bellemare et al. (2008) argue that experiments are particularly useful for understanding consumers' economic decision making. Not surprisingly, research into choice under risk typically employs an experimental approach (Ellsberg 1961; Halevy 2007; Baillon and Bleichrodt 2015). Our experiment implements a revealed preference (in contrast to a stated preference) design to provide evidence concerning consumer choice and the difference between Risk Aversion and Ambiguity Aversion. Although some may argue the use of experiments does not indicate how people would make decisions in the real life, Gneezy et al. (2006) find that participants answer questions in the same way in both hypothetical and actual scenarios.

\section{Willingness to Pay in the Gain and Loss Domains}

Our experiment examines the relation between Risk Aversion and Ambiguity Aversion in both the gain and loss domains during the process of mortgage default settlement negotiations. The exact wording of all experimental treatments can be found in the appendix. Participants are informed they are in a dispute with their mortgage lender with two possible outcomes. In the gain (loss) domain, they will potentially have a decrease (increase) in the mortgages unpaid balance (UPB) by either $\$ 30,000$ or $\$ 80,000$. The risky treatment provides the probability that each choice will occur, while the ambiguous treatment states they "have absolutely no idea how likely it is that either outcome will occur." Using a within-subjects design, participants see both the risk and ambiguous versions in both the gain and loss domains. Participants are then asked the amount they are willing to pay to lock in the more favorable result: reducing the UPB by $\$ 80,000$ in the gain domain and increasing the UPB by $\$ 30,000$ in the loss domain. Participants move a slider to record a value from $\$ 0$ to $\$ 50,000$, indicating their willingness to pay in each domain to achieve the more favorable outcome. The likelihood of a favorable outcome varies randomly from 0 to $100 \%$. To avoid presentation order effects, participants are randomly assigned to eight pools, with either the risk or ambiguous treatments in either the gain or loss domain before proceeding to the other treatments.

\section{Measuring Risk Aversion and Ambiguity Aversion}

An important aspect of understanding the relation between Risk Aversion and Ambiguity Aversion is being able to measure the degree of aversion for participants. Since Holt and Laury (2002), multiple price listing instruments have become a popular way to elicit risk preferences. ${ }^{2}$ These instruments are efficient in collecting risk preferences because they ask participants to choose between a series of gambles. Participants'

\footnotetext{
${ }^{2}$ See Charness et al. (2013) for a thorough discussion of methods to measure risk preferences.
} 
choices reveal underlying Risk Aversion levels. Accordingly, we assess each participant's Risk Aversion and Ambiguity Aversion using the multiple price listing instruments of Gneezy et al. (2015). This instrument is based on an $\alpha$-MEU model developed by Ghirardato et al. (2004) with a constant relative Risk Aversion and von-NeumannMorgenstern utilities.

\section{Personality}

The information gap literature maintains that both Risk Aversion and Ambiguity Aversion are rooted in people's discomfort with a lack of information (Loewenstein 1994; Golman and Loewenstein 2018; Golman et al. 2020). This implies personality may play a role in economic decision making. In fact, personality has been shown to be important in explaining market participation, day trading, and CEO performance (Lo et al. 2005; Peterson 2007; Puri and Robinson 2007; Borghans et al. 2008; Guiso et al. 2008; Kaplan et al. 2012). Altogether, the literature suggests experiments seeking to understand Risk Aversion and Ambiguity Aversion should include personality measures. There are several methods for discussing the traits that make up a personality. One of the most common is the Big Five personality factors (Borghans et al. 2008). Using factor analysis, this concept distills personality into five traits: conscientiousness, agreeableness, neuroticism, openness to experience, and extraversion. Several studies of financial choice have found trust, a component of agreeableness, to be an important factor in financial decisions (Guiso et al. 2008; Dimmock et al. 2016). We control for personality traits using Rammstedt and John's (2007) Big Five Personality Instrument.

\section{Financial Literacy and Demographics}

Studies show that financial literacy and demographics may influence economic decisions (Guiso et al. 2008; Van Rooij et al. 2011; Lusardi and Mitchell 2014; Dimmock et al. 2016). Furthermore, Golman and Loewenstein (2018) find that personal preferences and competencies may also play a role in Ambiguity Aversion. That is, people may display higher levels of Ambiguity Aversion in subjects they dislike, with which they are unfamiliar, or in which they lack skill. We therefore include a financial literacy control variable constructed with five questions from the FINRA Investor Education Foundation (Zahirovic-Herbert et al. 2016) ${ }^{3}$ and demographic variables including the Male dummy that takes the value of 1 if male, and 0 otherwise; the White dummy that takes the value of 1 if the participant is White, and 0 otherwise; the Number of dependent children; the Married dummy that takes the value of 1 if married, and 0 otherwise; and the participant's Age in years.

\section{Sample}

Research into economic decision making is often conducted using a small sample primarily consisting of students (Holt and Laury 2002; Gneezy et al. 2006; Halevy

\footnotetext{
${ }^{3}$ Please see the appendix for details of FINRA's five questions.
} 
2007; Baillon and Bleichrodt 2015). While student samples are convenient and may be instructive, they are clearly not representative of the overall population. Students are generally younger and have less life and financial experience than the population at large. Recently, several studies have employed surveys to investigate the ability of Ambiguity Aversion to explain financial puzzles, including underdiversification and underparticipation in equity markets and the timing of stock option exercises (Dimmock et al. 2015; Dimmock et al. 2016; Peijnenburg 2018). We follow this line of research by using a large, ${ }^{4}$ national, sample collected via a MTurk, an established online clearinghouse. This clearinghouse provides several functions helpful in conducting our experiment. For a nominal fee, it maintains the anonymity of participants and provides a method for compensating them. The clearinghouse also has a rating system allowing researchers to assess the quality of participants. To increase the accuracy and reliability of our results, participants must have at least a $95 \%$ approval rating to take part in our experiments. In addition to the clearinghouse's quality control measures, we also institute our own methods to ensure participants are carefully considering their responses and to reduce noise in the data. To ensure they understand the experiment, the first validity check requires participants to spend at least $5 \mathrm{~s}$ reading the initial instruction page. ${ }^{5}$ The second validity check requires them to select the numbers "9" and "2" in response to two separate questions. ${ }^{6}$ Our initial dataset included 2457 observations. Of those, 86 observations were discarded because participants failed to take the required time to read the instructions, and 529 observations were discarded because they failed at least one of our internal validity checks. Twentyfive additional observations were missing descriptive characteristics, leaving a final sample of 1817 - a very large sample for experiments of this kind.

One advantage of a large, national sample is that it is in many ways representative of the United States as a whole, which increases the generalizability of the results. The sample includes participants from all 50 states and Washington, D.C. with demographics similar to those of homeowners, in general. Table 1 reports the descriptive demographics and behavioral characteristics of the sample. Participants are 52\% male, $62 \%$ are married, and have an average of 1.14 children. The average participant age is 37 years, somewhat younger than the average homeowner. Our sample identifies as $74 \%$ White, a similar percentage as the United States in total $(77 \%)^{7}$

Since our experiment involves mortgage default settlements, we create controls for financial history, including default history, financial literacy, net worth, and income. Fifteen percent of the sample has previously defaulted on a mortgage at some point in their lifetime. Most of the sample $(72 \%)$ has a positive net worth, with a mean income level between $\$ 40,000$ and $\$ 60,000$. On average, participants correctly answered three

\footnotetext{
${ }^{4}$ Our sample is roughly twice that used in Dimmock et al. (2015).

${ }^{5}$ We place hidden timers on every page of the experiment.

${ }^{6}$ Although the experimental literature often provides monetary incentives to encourage participants to make careful choices, this study does not include such payments for several reasons. First, the inclusion of incentives may influence the participants' Risk Seeking behavior (Thaler and Johnson 1990; Weber and Zuchel 2005; Ackert et al. 2006; Azrieli et al. 2018). Second, our questions do not have correct answers which makes rewarding correctness impossible. Third, since some of our trials are in the loss domain. As such, devising an appropriate incentive mechanism is nontrivial.

${ }^{7}$ U.S. ethnicity percentages are population estimates by the U.S. Census Bureau: https://www.census.gov/ quickfacts/fact/table/US/RHI225217\#RHI225217.
} 
financial literacy questions out of the five possible from the FINRA Investor Education Foundation inventory.

Risk Aversion and Ambiguity Aversion are measured for each participant using the instruments found in Gneezy et al. (2015). On a scale from 1 (risk/ambiguity seeking) to 11 (risk/ambiguity averse), our sample means are 6.39 and 6.54 for Risk Aversion and Ambiguity Aversion, respectively. This result is in line with prior literature suggesting that, in general, people tend to be Risk and Ambiguity Averse.

The Big Five Personality traits are measured using the Rammstedt and John (2007) instrument. Openness refers to openness to experience and is defined by creativity and thirst for knowledge. Extraversion is the degree to which one is outgoing and talkative. Agreeableness measures how pleasant and trusting one is. Neuroticism is also called emotional stability and reflects how much a person sees the world as threatening. Conscientiousness is the degree to which one is organized and complies with norms. Further information about personality traits can be found in Costa and McCrae (1992) and Borghans et al. (2008). Each personality trait is assessed using the results of two questions, except Agreeableness, which includes three questions. The participant is asked to rate on a scale from 1 to 5 if he sees himself as someone with different characteristics. The instrument reverse scores some questions to increase reliability. The personality scores reported in Table 1 reflect the addition of the results to the two or three questions assigned to each personality trait. Full questions for this instrument are reported in the appendix.

Recall that our research design includes eight pools to mitigate presentation order effects. For simplicity of presentation, we collapse these within-subjects results, but test to ensure our participant characteristics are balanced among the pools. If participant characteristics are not equally distributed among the pools, our sample may be unbalanced and our empirical results may suffer from endogeneity. Accordingly, we perform one-way ANOVA tests for equality for each participant characteristic variable across the eight pools (Armona et al. 2019). The non-significant ANOVA results confirm our variables are equitably balanced across the pools, reducing endogeneity concerns.

Table 2 provides pairwise correlations for the key study variables. Not surprisingly, Risk Aversion and Ambiguity Aversion are positively correlated. However, although personal characteristics are somewhat correlated with Ambiguity Aversion and Risk Aversion, they are not similar across both aversion measures, which supports the literature suggesting they are separate phenomena. Moving on to the financial history variables, financial literacy is positively related to both Ambiguity Aversion and Risk Aversion. Although some relations between the variables are significant, the correlations do not rise to the level that would be a concern for mulit-collinearity in our regressions.

\section{Results}

This experiment is designed to assess the effect of Ambiguity Aversion on real estate decision making as it relates to mortgage default settlements in both the gain and loss domains, testing the predictions of prospect theory (Kahneman and Tversky 1979). By conducting an experiment where all respondents see both scenarios, we are able to examine differences between the risk and ambiguity scenarios. The literature suggests 
Table 1 Descriptive statistics

\begin{tabular}{|c|c|c|c|c|c|c|}
\hline Variable & Obs. & Mean & Std.Dev. & Min & $\operatorname{Max}$ & $P$ value \\
\hline \multicolumn{7}{|l|}{ Demographics } \\
\hline Male dummy & 1817 & 0.524 & 0.500 & 0 & 1 & 0.771 \\
\hline White dummy & 1817 & 0.741 & 0.438 & 0 & 1 & 0.488 \\
\hline Number dependent children & 1817 & 1.139 & 1.316 & 0 & 9 & 0.426 \\
\hline Married dummy & 1817 & 0.624 & 0.484 & 0 & 1 & 0.268 \\
\hline Age & 1817 & 37.337 & 11.521 & 18 & 86 & 0.158 \\
\hline \multicolumn{7}{|l|}{ Financial History } \\
\hline Positive net worth dummy & 1817 & 0.717 & 0.451 & 0 & 1 & 0.757 \\
\hline Income & 1817 & 3.418 & 1.567 & 1 & 7 & 0.969 \\
\hline Financial literacy & 1817 & 3.529 & 1.289 & 0 & 5 & 0.338 \\
\hline Previous default dummy & 1817 & 0.150 & 0.357 & 0 & 1 & 0.572 \\
\hline \multicolumn{7}{|l|}{ Big Five Personality Traits } \\
\hline Openness & 1817 & 7.086 & 1.865 & 2 & 10 & 0.830 \\
\hline Extraversion & 1817 & 5.561 & 2.036 & 2 & 10 & 0.388 \\
\hline Agreeableness & 1817 & 11.121 & 2.340 & 3 & 15 & 0.215 \\
\hline Neuroticism & 1817 & 5.210 & 2.103 & 2 & 10 & 0.143 \\
\hline Conscientiousness & 1817 & 7.791 & 1.797 & 2 & 10 & 0.578 \\
\hline \multicolumn{7}{|l|}{ Aversion Scores } \\
\hline Ambiguity Aversion & 1817 & 6.540 & 3.312 & 1 & 11 & 0.545 \\
\hline Ambiguity Aversion Category & 1817 & 1.520 & 0.798 & 0 & 2 & 0.186 \\
\hline Risk Aversion & 1817 & 6.393 & 2.968 & 1 & 11 & 0.304 \\
\hline Risk Aversion Category & 1817 & 1.605 & 0.749 & 0 & 2 & 0.934 \\
\hline
\end{tabular}

This table reports the descriptive summary statistics for study variables. Demographics include the Male dummy that takes the value of 1 if male, and 0 otherwise; the White dummy that takes the value of 1 if the participant is White, and 0 otherwise; the Number of dependent children; the Married dummy that takes the value of 1 if married, and 0 otherwise; and the participant's Age in years. Financial History variables include a Positive net worth dummy that takes the value of 1 if the participant has positive net worth and 0 otherwise; Income on a scale from 1 (under $\$ 20,000$ ) to 7 (over $\$ 120,000$ ); Financial literacy reports the number of correct responses to the five financial literacy questions from FINRA; and the Previous default dummy takes the value of 1 if the participant has previously defaulted on a mortgage, and 0 otherwise. Big Five Personality Traits include Openness, Extraversion, Agreeableness, Neuroticism, and Conscientiousness, as measured by the Rammstedt and John (2007) instrument. Aversion Scores include Ambiguity Aversion and Risk Aversion measured using the multiple price list instrument developed by Gneezy et al. (2015) and the corresponding variables, Ambiguity Aversion Category and Risk Aversion Category, which range from Ambiguity or Risk Seeking (Level 0) to Ambiguity or Risk Averse (Level 2). $P$ values are from one-way ANOVA tests for equality across the subject pools

Risk Aversion and Ambiguity Aversion are sensitive to the environment in which they are studied, so this method of assessing Ambiguity Aversion may be important (Golman and Loewenstein 2018).

With these important differences in mind, we now present results for the amount of money participants are willing to pay to guarantee a reduction in their UPB by $\$ 80,000$ during a default settlement negotiation versus a reduction in the UPB by $\$ 30,000$. This is in the gain domain because both options involve a reduction in UPB. Panel A of Fig. 1 plots the mean dollar amount participants are willing to pay for each probability 


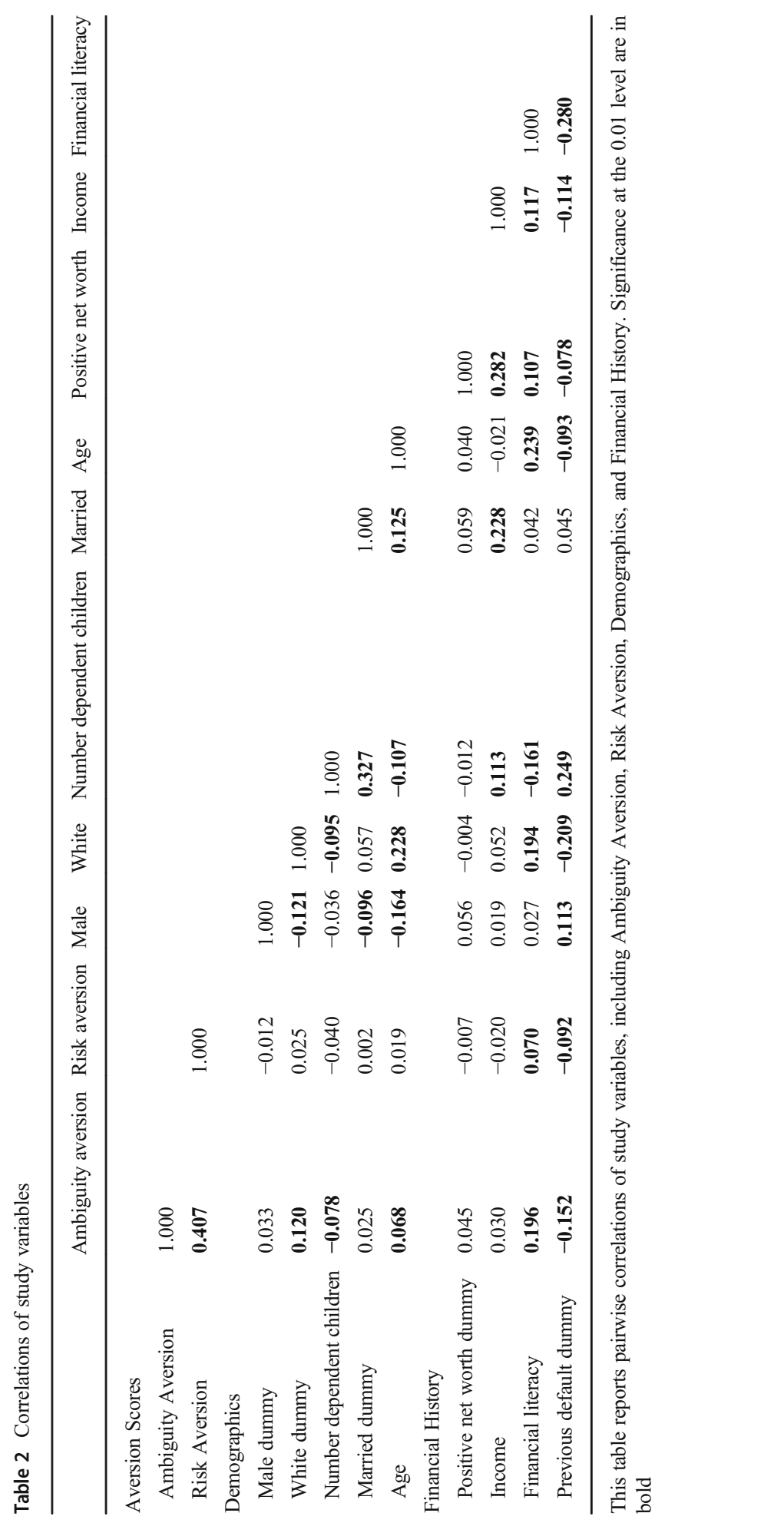



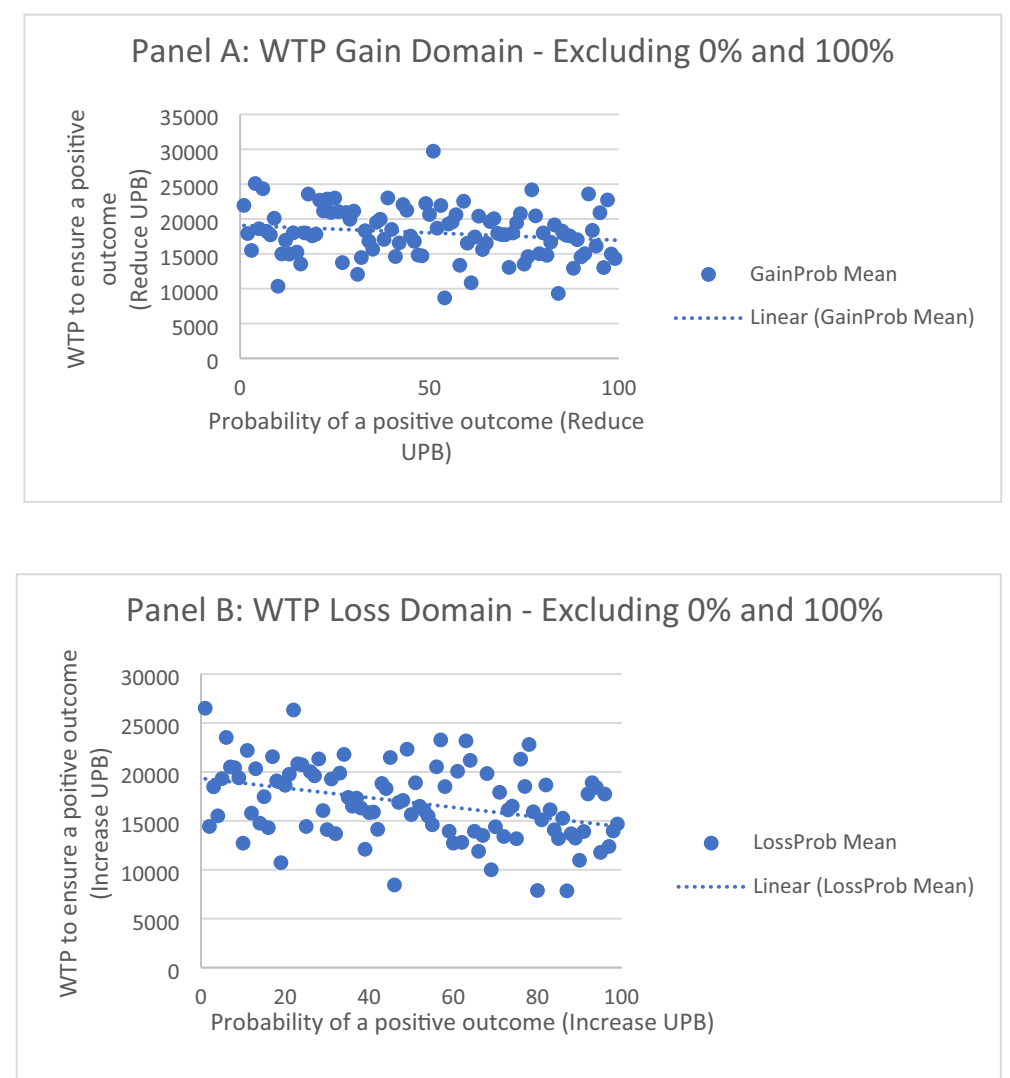

Fig. 1 Willingness to pay (WTP) to ensure a positive outcome, excluding 0\% and $100 \%$. Panel A shows the mean dollar amount participants are willing to pay to guarantee a greater UPB reduction (gain domain) for each probability of a positive outcome, excluding sure bets (i.e., $0 \%$ and 100\%). Panel B plots results in the loss domain

of a positive outcome. As expected, as the likelihood of a positive outcome increases, the amount participants are willing to pay to ensure the reduction in their UPB by $\$ 80,000$ declines, resulting in a trendline with a negative slope. Next, we repeat the experiment in the loss domain. Panel B of Fig. 1 displays the mean amount participants are willing to pay to lock in a $\$ 30,000$ increase in their UPB versus an $\$ 80,000$ increase per probability of a positive outcome. Note that in the loss domain, the positive outcome is still a loss of $\$ 30,000$.

Panel A of Table 3 reports the amount participants are willing to pay to lock in the $\$ 80,000$ UPB reduction separated by Ambiguity Aversion category. We expect Ambiguity Seeking participants to be more comfortable with ambiguity and would therefore expect them to be willing to pay less to ensure the positive result than Ambiguity Averse respondents. However, the results in Table 3 show the opposite: Ambiguity Seeking participants are willing to pay more than Ambiguity Averse participants to ensure a positive outcome. We will explain this result momentarily.

Panel B reports the mean amount participants are willing to pay for each category of Ambiguity Aversion. Consistent with Panel A, we find that Ambiguity Seeking 
Table 3 Summary statistics for willingness to pay in the gain and loss domains

\begin{tabular}{|c|c|c|c|c|c|}
\hline & Obs. & Mean WTP (\$) & Std.Dev. & Min & Max \\
\hline \multicolumn{6}{|l|}{ Panel A: Gain Domain } \\
\hline \multicolumn{6}{|c|}{ Ambiguity Aversion Category } \\
\hline Ambiguity Averse & 1295 & $18,178.28$ & $13,983.82$ & 0 & 50,000 \\
\hline Ambiguity Neutral & 171 & $18,942.12$ & $14,435.57$ & 0 & 50,000 \\
\hline Ambiguity Seeking & 351 & $20,621.12$ & $14,529.97$ & 0 & 50,000 \\
\hline Total & 1817 & $18,722.06$ & $14,147.95$ & 0 & 50,000 \\
\hline \multicolumn{6}{|l|}{ Panel B: Loss Domain } \\
\hline \multicolumn{6}{|c|}{ Ambiguity Aversion Category } \\
\hline Ambiguity Averse & 1295 & $15,996.97$ & $13,296.95$ & 0 & 50,000 \\
\hline Ambiguity Neutral & 171 & $17,318.05$ & $13,782.43$ & 0 & 50,000 \\
\hline Ambiguity Seeking & 351 & $18,741.17$ & $14,044.23$ & 0 & 50,000 \\
\hline Total & 1817 & $16,651.41$ & $13,526.79$ & 0 & 50,000 \\
\hline
\end{tabular}

Panel A reports statistics for participants' willingness to pay (WTP) to ensure a positive result from default settlement negotiations in the gain domain, ranging from $\$ 0$ to $\$ 50,000$. Possible outcomes are a decrease in the UPB by $\$ 80,000$ or $\$ 30,000$. Panel B reports statistics for participants' willingness to pay to ensure a positive result from default settlement negations in the loss domain, ranging from $\$ 0$ to $\$ 50,000$. Possible outcomes are an increase in the UPB by $\$ 80,000$ or $\$ 30,000$. All results are in ambiguous conditions where probabilities of the default settlement working out in participants' favor are not disclosed. Data are reported in total and by Ambiguity Aversion Category

participants are willing to pay more than Ambiguity Averse participants to ensure a more positive outcome. At first, these results might seem counterintuitive. However, the experimental design introduces an element of funds availability. In this scenario, if the outcomes are equally likely, the expected payoff would be a $\$ 25,000$ reduction in UPB in the gain domain or a $\$ 25,000$ increase in UPB in the loss domain. Participants with sufficient funds would be expected to pay an amount approaching $\$ 25,000$. However, some participants may not have the funds available to make the payment. This line of thinking suggests that in areas of a quantified payment amount, controlling for financial history is important, which we do next.

Table 4 displays robust regression results in which the dependent variable is the amount participants are willing to pay to ensure a positive result in the loss domain for Columns 1, 2, and 3 and in the gain domain for Columns 4, 5, and 6. As in Table 3, Columns 1 and 4 show a negative relation between Ambiguity Aversion and the willingness to pay to guarantee a positive result. Columns 2 and 5 show the negative result is robust to adding Risk Aversion to the regression and robust to other controls in Columns 3 and 6. Similar to previous findings that Ambiguity Aversion leads people to avoid participating in the stock market (Dow and Werlang 1992; Easley and O'Hara 2009), we find that Ambiguity Averse borrowers are less willing to pay to resolve the uncertainty of mortgage default settlements. Since Ambiguity Averse people prefer known probabilities to unknown uncertainties, they may be unwilling to invest in assuring a positive outcome in settlement proceeedings. Positive net worth, higher income, previous default, and the male dummy variable are positively associated with higher payments. The White dummy variable, age, and financial literacy are negatively 


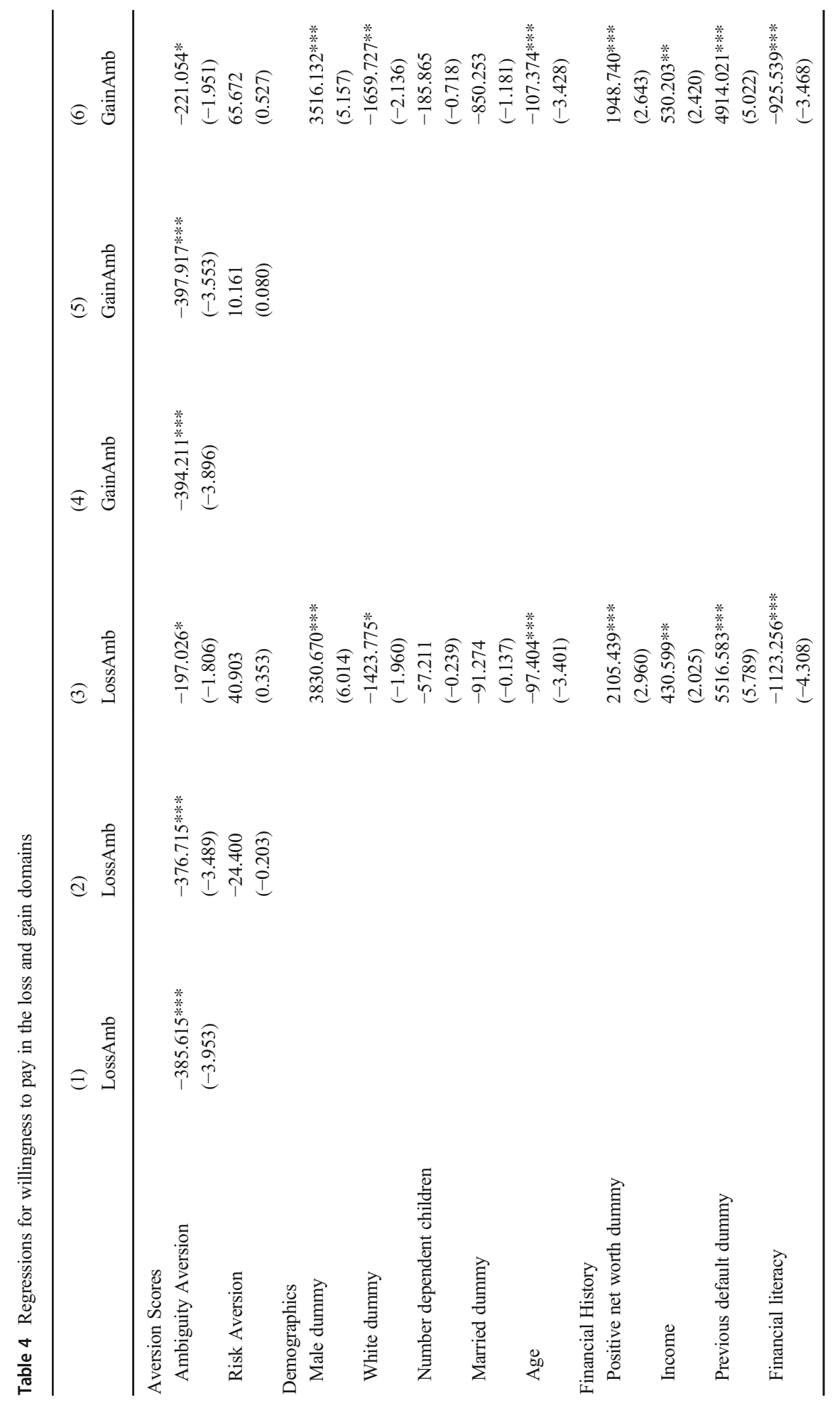




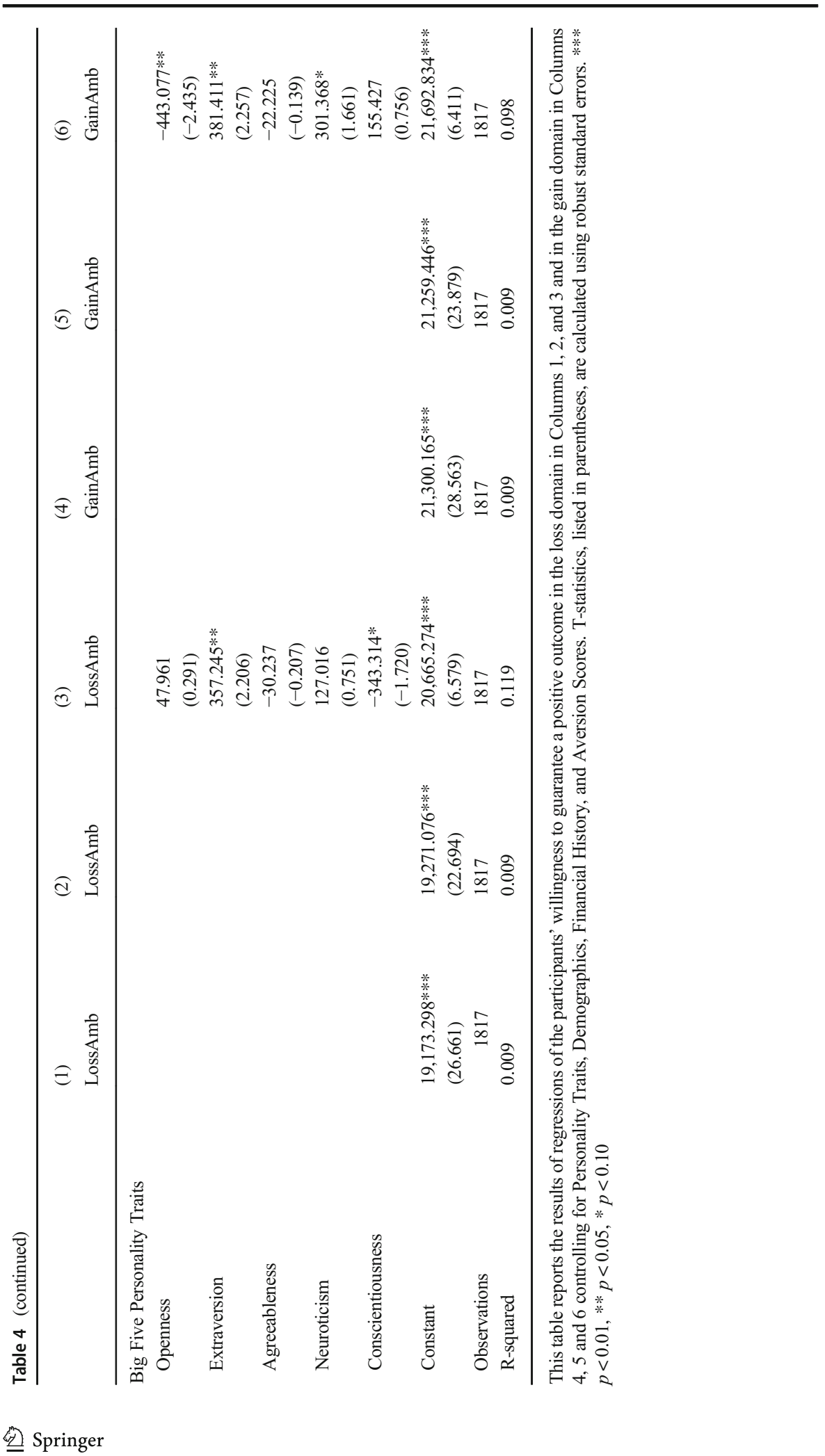


associated with the amount people are willing to pay. Financial literacy may be associated with a greater confidence in being able to handle the repercussions from the mortgage default settlement. This greater confidence results in financially literate participants being willing to pay less to resolve the issue than participants with less financial knowledge. Extraversion is positively related to the amount people are willing to pay in both the gain and loss domains, while openness is negatively associated with willingness to pay in the gain domain only. The positive and significant coefficients on income and positive net worth dummy confirm our interpretation of Table 3. Participants' financial histories should be accounted for when investigating the amount they are willing to pay. We further investigate the effect of financial histories in the following analyses.

\section{Robustness Checks}

This first series of robustness tests are conducted in the loss domain with results reported in Table 5. First, we split the sample by high and low financial literacy in Columns 1 and 2 and by whether the participant has previously defaulted on a loan or not in Columns 3 and 4. Participants deemed to possess high financial literacy are those who answered all of the FINRA literacy questions correctly. Ambiguity Aversion is again robust to the inclusion of control variables, but only for participants who have high financial literacy and have not previously defaulted on a loan. For lower financial literacy and those who have defaulted on a loan, Ambiguity Aversion remains nonsignificant.

We next estimate the same series of robustness tests in the gain domain and find similar, but stronger results, which are reported in Table 6. Compared to the results in the loss domain, we find Ambiguity Aversion is negatively related to the amount participants are willing to pay if they have a high level of financial literacy or no previous default history. Both these results are significant at the $99 \%$ level. $^{8}$

\section{Conclusion}

The mortgage market is associated with a high degree of financial leverage, represents a substantial percentage of a borrower's balance sheet, and when in default, brings about an unparalleled degree of legal ambiguity. These factors come together to make a mortgage default settlement negotiation the ideal laboratory for examining and differentiating between the roles of Risk and Ambiguity Aversion.

Using a large, national sample, we perform a series of experiments to examine the relation between risky decisions and decisions under ambiguous conditions as it relates to mortgage default settlements. Our results suggest that Risk Aversion and Ambiguity Aversion are best studied together. The amount a person is willing to pay to achieve a positive outcome depends not only on the Ambiguity or Risk Aversion level, but also on financial history and demographic characteristics.

\footnotetext{
${ }^{8}$ As a final robustness check, we also perform both censored tobit and ordered probit regressions. Our results remain qualitatively unchanged and are available from the authors upon request.
} 
Table 5 Robustness checks for willingness to pay regressions in the loss domain

\begin{tabular}{|c|c|c|c|c|}
\hline & $\begin{array}{l}\text { (1) } \\
\text { High Financial } \\
\text { Literacy }\end{array}$ & $\begin{array}{l}\text { (2) } \\
\text { Low Financial } \\
\text { Literacy }\end{array}$ & $\begin{array}{l}(3) \\
\text { No Previous } \\
\text { Default }\end{array}$ & $\begin{array}{l}(4) \\
\text { Previous } \\
\text { Default }\end{array}$ \\
\hline & LossAmb & LossAmb & LossAmb & LossAmb \\
\hline \multicolumn{5}{|l|}{ Aversion Scores } \\
\hline Ambiguity Aversion & $\begin{array}{l}-282.175^{*} \\
(-1.940)\end{array}$ & $\begin{array}{l}-86.409 \\
(-0.531)\end{array}$ & $\begin{array}{l}-200.354^{*} \\
(-1.721)\end{array}$ & $\begin{array}{l}70.108 \\
(0.232)\end{array}$ \\
\hline Risk Aversion & $\begin{array}{l}114.910 \\
(0.667)\end{array}$ & $\begin{array}{l}17.119 \\
(0.110)\end{array}$ & $\begin{array}{l}-43.968 \\
(-0.345)\end{array}$ & $\begin{array}{l}391.169 \\
(1.433)\end{array}$ \\
\hline \multicolumn{5}{|l|}{ Demographics } \\
\hline Male dummy & $\begin{array}{l}2278.980 * * * \\
(2.699)\end{array}$ & $\begin{array}{l}5442.024 * * * \\
(5.535)\end{array}$ & $\begin{array}{l}3324.801 * * * \\
(4.778)\end{array}$ & $\begin{array}{l}6165.373 * * * \\
(3.502)\end{array}$ \\
\hline White dummy & $\begin{array}{l}-580.351 \\
(-0.548)\end{array}$ & $\begin{array}{l}-2050.264 * * \\
(-2.056)\end{array}$ & $\begin{array}{l}-905.600 \\
(-1.127)\end{array}$ & $\begin{array}{l}-3418.135^{* *} \\
(-2.121)\end{array}$ \\
\hline Number dependent children & $\begin{array}{l}-332.517 \\
(-0.927)\end{array}$ & $\begin{array}{l}25.951 \\
(0.080)\end{array}$ & $\begin{array}{l}-278.512 \\
(-0.986)\end{array}$ & $\begin{array}{l}-24.723 \\
(-0.058)\end{array}$ \\
\hline Married dummy & $\begin{array}{l}-731.015 \\
(-0.801)\end{array}$ & $\begin{array}{l}1054.039 \\
(1.081)\end{array}$ & $\begin{array}{l}-117.092 \\
(-0.162)\end{array}$ & $\begin{array}{l}474.783 \\
(0.285)\end{array}$ \\
\hline Age & $\begin{array}{l}-67.887 * \\
(-1.837)\end{array}$ & $\begin{array}{l}-155.657 * * * \\
(-3.447)\end{array}$ & $\begin{array}{l}-76.619 * * \\
(-2.478)\end{array}$ & $\begin{array}{l}-175.432 * * \\
(-2.229)\end{array}$ \\
\hline \multicolumn{5}{|l|}{ Financial History } \\
\hline Positive net worth dummy & $\begin{array}{l}2497.729 * * * \\
(2.627)\end{array}$ & $\begin{array}{l}550.593 \\
(0.511)\end{array}$ & $\begin{array}{l}1963.219 * * \\
(2.519)\end{array}$ & $\begin{array}{l}1116.672 \\
(0.601)\end{array}$ \\
\hline Income & $\begin{array}{l}299.115 \\
(1.086)\end{array}$ & $\begin{array}{l}852.199 * * \\
(2.504)\end{array}$ & $\begin{array}{l}262.158 \\
(1.158)\end{array}$ & $\begin{array}{l}1624.813^{* * * *} \\
(2.707)\end{array}$ \\
\hline Previous default dummy & $\begin{array}{l}3440.725 * * \\
(2.006)\end{array}$ & $\begin{array}{l}5763.519 * * * \\
(4.910)\end{array}$ & & \\
\hline Financial literacy & & & $\begin{array}{l}-1048.973 * * * \\
(-3.720)\end{array}$ & $\begin{array}{l}-1472.801 * * \\
(-1.969)\end{array}$ \\
\hline \multicolumn{5}{|l|}{ Big Five Personality Traits } \\
\hline Openness & $\begin{array}{l}89.009 \\
(0.430)\end{array}$ & $\begin{array}{l}-67.787 \\
(-0.246)\end{array}$ & $\begin{array}{l}23.430 \\
(0.136)\end{array}$ & $\begin{array}{l}31.554 \\
(0.061)\end{array}$ \\
\hline Extraversion & $\begin{array}{l}188.647 \\
(0.920)\end{array}$ & $\begin{array}{l}671.549 * * \\
(2.550)\end{array}$ & $\begin{array}{l}321.394 * \\
(1.908)\end{array}$ & $\begin{array}{l}1058.128 * * \\
(2.066)\end{array}$ \\
\hline Agreeableness & $\begin{array}{l}15.161 \\
(0.080)\end{array}$ & $\begin{array}{l}-14.664 \\
(-0.062)\end{array}$ & $\begin{array}{l}-159.371 \\
(-1.053)\end{array}$ & $\begin{array}{l}1032.134 * * \\
(2.105)\end{array}$ \\
\hline Neuroticism & $\begin{array}{l}133.429 \\
(0.600)\end{array}$ & $\begin{array}{l}68.776 \\
(0.261)\end{array}$ & $\begin{array}{l}109.736 \\
(0.621)\end{array}$ & $\begin{array}{l}104.096 \\
(0.200)\end{array}$ \\
\hline Conscientiousness & $\begin{array}{l}-91.587 \\
(-0.340)\end{array}$ & $\begin{array}{l}-634.350 * * \\
(-2.039)\end{array}$ & $\begin{array}{l}-193.978 \\
(-0.896)\end{array}$ & $\begin{array}{l}-1599.169 * * * \\
(-3.353)\end{array}$ \\
\hline Constant & $\begin{array}{l}13,685.147 * * * \\
(3.238)\end{array}$ & $\begin{array}{l}\text { 19,423.308*** } \\
(4.115)\end{array}$ & $\begin{array}{l}21,679.332 * * * \\
(6.561)\end{array}$ & $\begin{array}{l}15,782.484 * \\
(1.751)\end{array}$ \\
\hline Observations & 1032 & 785 & 1545 & 272 \\
\hline R-squared & 0.033 & 0.194 & 0.056 & 0.269 \\
\hline
\end{tabular}

This table reports the results of regressions of the participants' willingness to guarantee a positive outcome in the loss domain. Columns 1 and 2 split the sample for high and low Financial Literacy, while Columns 3 and 4 split the sample by previous default experience. T-statistics, listed in parentheses, are calculated using robust standard errors. $* * * p<0.01, * * p<0.05, * p<0.10$ 
Table 6 Robustness checks for willingness to pay regressions in the gain domain

\begin{tabular}{|c|c|c|c|c|}
\hline & (1) & (2) & (3) & (4) \\
\hline & $\begin{array}{l}\text { High Financial } \\
\text { Literacy } \\
\text { GainAmb }\end{array}$ & $\begin{array}{l}\text { Low Financial } \\
\text { Literacy } \\
\text { GainAmb }\end{array}$ & $\begin{array}{l}\text { No Previous } \\
\text { Default } \\
\text { GainAmb }\end{array}$ & $\begin{array}{l}\text { Previous } \\
\text { Default } \\
\text { GainAmb }\end{array}$ \\
\hline \multicolumn{5}{|l|}{ Aversion Scores } \\
\hline Ambiguity Aversion & $\begin{array}{l}-405.672 * * * \\
(-2.674)\end{array}$ & $\begin{array}{l}8.373 \\
(0.050)\end{array}$ & $\begin{array}{l}-268.764 * * \\
(-2.222)\end{array}$ & $\begin{array}{l}168.658 \\
(0.537)\end{array}$ \\
\hline Risk Aversion & $\begin{array}{l}194.602 \\
(1.070)\end{array}$ & $\begin{array}{l}-66.015 \\
(-0.388)\end{array}$ & $\begin{array}{l}0.397 \\
(0.003)\end{array}$ & $\begin{array}{l}358.475 \\
(1.221)\end{array}$ \\
\hline \multicolumn{5}{|l|}{ Demographics } \\
\hline Male dummy & $\begin{array}{l}2031.745^{* * *} \\
(2.254)\end{array}$ & $\begin{array}{l}5587.624 * * * \\
(5.347)\end{array}$ & $\begin{array}{l}3410.520 * * * \\
(4.579)\end{array}$ & $\begin{array}{l}3800.004 * * \\
(2.116)\end{array}$ \\
\hline White dummy & $\begin{array}{l}-1175.971 \\
(-1.028)\end{array}$ & $\begin{array}{l}-2177.706^{* * *} \\
(-2.080)\end{array}$ & $\begin{array}{l}-1724.114 * * \\
(-1.979)\end{array}$ & $\begin{array}{l}-1893.802 \\
(-1.094)\end{array}$ \\
\hline Number dependent children & $\begin{array}{l}140.001 \\
(0.356)\end{array}$ & $\begin{array}{l}-389.051 \\
(-1.131)\end{array}$ & $\begin{array}{l}-137.764 \\
(-0.437)\end{array}$ & $\begin{array}{l}-339.409 \\
(-0.751)\end{array}$ \\
\hline Married dummy & $\begin{array}{l}-2637.111 * * * \\
(-2.646)\end{array}$ & $\begin{array}{l}1131.982 \\
(1.071)\end{array}$ & $\begin{array}{l}-1287.895 \\
(-1.615)\end{array}$ & $\begin{array}{l}1257.888 \\
(0.701)\end{array}$ \\
\hline Age & $\begin{array}{l}-111.757 * * * \\
(-2.848)\end{array}$ & $\begin{array}{l}-94.567 * \\
(-1.781)\end{array}$ & $\begin{array}{l}-104.196 * * * \\
(-3.142)\end{array}$ & $\begin{array}{l}-143.474 \\
(-1.590)\end{array}$ \\
\hline \multicolumn{5}{|l|}{ Financial History } \\
\hline Positive net worth dummy & $\begin{array}{l}2352.723 * * \\
(2.369)\end{array}$ & $\begin{array}{l}410.335 \\
(0.366)\end{array}$ & $\begin{array}{l}1879.549 * * \\
(2.301)\end{array}$ & $\begin{array}{l}1815.627 \\
(1.021)\end{array}$ \\
\hline Income & $\begin{array}{l}120.350 \\
(0.421)\end{array}$ & $\begin{array}{l}1303.164 * * * \\
(3.932)\end{array}$ & $\begin{array}{l}463.492 * \\
(1.958)\end{array}$ & $\begin{array}{l}999.652 * \\
(1.764)\end{array}$ \\
\hline Previous default dummy & $\begin{array}{l}5527.334 * * * \\
(3.280)\end{array}$ & $\begin{array}{l}4409.868 * * * \\
(3.646)\end{array}$ & & \\
\hline Financial literacy & & & $\begin{array}{l}-977.447 * * * \\
(-3.359)\end{array}$ & $\begin{array}{l}-339.177 \\
(-0.472)\end{array}$ \\
\hline \multicolumn{5}{|l|}{ Big Five Personality Traits } \\
\hline Openness & $\begin{array}{l}-456.775 * * \\
(-2.007)\end{array}$ & $\begin{array}{l}-534.661 * \\
(-1.745)\end{array}$ & $\begin{array}{l}-492.526 * * * \\
(-2.595)\end{array}$ & $\begin{array}{l}-2.744 \\
(-0.005)\end{array}$ \\
\hline Extraversion & $\begin{array}{l}264.514 \\
(1.262)\end{array}$ & $\begin{array}{l}672.864 * * \\
(2.408)\end{array}$ & $\begin{array}{l}257.553 \\
(1.450)\end{array}$ & $\begin{array}{l}1712.965 * * * \\
(3.074)\end{array}$ \\
\hline Agreeableness & $\begin{array}{l}-239.032 \\
(-1.197)\end{array}$ & $\begin{array}{l}353.250 \\
(1.343)\end{array}$ & $\begin{array}{l}22.400 \\
(0.133)\end{array}$ & $\begin{array}{l}-365.651 \\
(-0.707)\end{array}$ \\
\hline Neuroticism & $\begin{array}{l}-62.869 \\
(-0.268)\end{array}$ & $\begin{array}{l}682.559 * * \\
(2.340)\end{array}$ & $\begin{array}{l}266.522 \\
(1.380)\end{array}$ & $\begin{array}{l}776.132 \\
(1.421)\end{array}$ \\
\hline Conscientiousness & $\begin{array}{l}217.743 \\
(0.818)\end{array}$ & $\begin{array}{l}-54.351 \\
(-0.163)\end{array}$ & $\begin{array}{l}306.379 \\
(1.379)\end{array}$ & $\begin{array}{l}-782.496 \\
(-1.497)\end{array}$ \\
\hline Constant & $\begin{array}{l}24,847.492 * * * \\
(5.351)\end{array}$ & $\begin{array}{l}10,139.310 * * \\
(1.998)\end{array}$ & $\begin{array}{l}22,637.904 * * * \\
(6.305)\end{array}$ & $\begin{array}{l}16,925.909^{*} \\
(1.708)\end{array}$ \\
\hline Observations & 1032 & 785 & 1545 & 272 \\
\hline R-squared & 0.062 & 0.138 & 0.064 & 0.159 \\
\hline
\end{tabular}

This table reports the results of regressions of the participants' willingness to guarantee a positive outcome in the gain domain. Columns 1 and 2 split the sample for high and low Financial Literacy, while Columns 3 and 4 split the sample by previous default experience. T-statistics, listed in parentheses, are calculated using robust standard errors. *** $p<0.01, * * p<0.05, * p<0.10$ 
Specifically, Ambiguity Aversion is negatively associated with willingness to pay in both the gain and loss domains. This is consistent with Ambiguity Averse people abstaining from stock market participation. However, after parsing the sample, this result is only evident for participants who are highly financially literate. Low financial literacy participants do not have an association between Ambiguity Aversion and WTP. We also find that personality traits are only associated with WTP for the low financial literacy group. Taken together, our findings are consistent with the idea that financially literate borrowers are influenced by Ambiguity Aversion in financial decision making, but low financial literacy borrowers are more influenced by their personality traits. These findings should help inform the strategy for providing financial education to borrowers who have defaulted on their loans.

\section{Appendix: Experiment Questions}

\section{Willingness to Pay - Risk Gain Domain Version (with Probabilities)}

You are currently involved in a legal dispute with your mortgage lender. Instead of leaving your loan balance unchanged, the court will DECREASE your outstanding mortgage balance by either (A) $\mathbf{\$ 3 0 , 0 0 0}$ or (B) $\mathbf{\$ 8 0 , 0 0 0}$. Indicate the maximum amount you would be willing to pay the lender to ensure Outcome B occurs before the court makes its ruling, given the following probability of each outcome.

[Randomized value from $0 \%$ to $100 \%$ ] Chance of Outcome (A) - Decrease mortgage balance by $\$ 30,000$

[100\%- chance of Outcome A] Chance of Outcome (B) - Decrease mortgage balance by $\$ 80,000$

Note: You must move the slider to register an answer.

Amounts are in dollars (\$)

$0 \quad 12500 \quad 25000 \quad 37500 \quad 50000$

My willingness to pay (in dollars)

\section{Willing to Pay - Ambiguous Gain Domain Version (Without Probabilities)}

You are currently involved in a legal dispute with your mortgage lender. Instead of leaving your loan balance unchanged, the court will DECREASE your outstanding mortgage balance by either (A) $\$ \mathbf{3 0 , 0 0 0}$ or (B) $\mathbf{\$ 8 0 , 0 0 0}$. You know that only one of these two outcomes will occur, but you have absolutely no idea how likely either outcome is to occur.

Indicate the maximum amount you would be willing to pay the lender to ensure Outcome B occurs before the court makes its ruling, knowing absolutely nothing about the probability of each outcome.

Note: You must move the slider to register an answer.

$$
\text { Amounts are in dollars (\$) }
$$

$0 \quad 12500 \quad 25000 \quad 37500 \quad 50000$

My willingness to pay (in dollars) () 


\section{Willingness to Pay - Risk Loss Domain Version (With Probabilities)}

You are currently involved in a legal dispute with your mortgage lender. Instead of leaving your loan balance unchanged, the court will INCREASE your outstanding mortgage balance by either (A) $\mathbf{\$ 3 0 , 0 0 0}$ or (B) $\mathbf{\$ 8 0 , 0 0 0}$. Indicate the maximum amount you would be willing to pay the lender to ensure Outcome A occurs before the court makes its ruling, given the following probability of each outcome.

[Randomized value from $0 \%$ to $100 \%$ ] Chance of Outcome (A) - Increase mortgage balance by $\$ \mathbf{\$ 3 0 , 0 0 0}$

[100\%- chance of Outcome A] Chance of Outcome (B) - Increase mortgage balance by \$80,000

Note: You must move the slider to register an answer.

Amounts are in dollars (\$)

$0 \quad 12500 \quad 25000 \quad 37500 \quad 50000$

My willingness to pay (in dollars) ()

Willingness to Pay - Ambiguous Loss Domain Version (without Probabilities)

You are currently involved in a legal dispute with your mortgage lender. Instead of leaving your loan balance unchanged, the court will INCREASE your outstanding mortgage balance by either (A) \$30,000 or (B) \$80,000. You know that only one of these two outcomes will occur, but you have absolutely no idea how likely either outcome is to occur.

Indicate the maximum amount you would be willing to pay the lender to ensure Outcome A occurs before the court makes its ruling, knowing absolutely nothing about the probability of each outcome.

Note: You must move the slider to register an answer.

Amounts are in dollars (\$)

$0 \quad 12500 \quad 25000 \quad 37500 \quad 50000$

My willingness to pay (in dollars) ()

Measure of Risk Aversion - Standard multiple price list instrument developed by Gneezy et al. (2015).

Hypothetical Example: Imagine you are investing a relatively large sum of money from your current assets.

Each row contains a pair of gambles, Options A and B. The expected payoff for each option is calculated for you. For example, in Row 1, Option A offers a 0 in 10 chance of earning 225 tokens and a 10 in 10 chance of earning 175 tokens. Therefore, the expected payoff is 175 tokens $[(0 / 10 * 225)+(10 / 10 * 175)]$. Option B has an expected payoff of $100[(0 / 10 * 400)+(10 / 10 * 100)]$. Everyone will prefer Option A because you are guaranteed 175 tokens, whereas in Option B, you are guaranteed only 100 tokens. Since we prefer Option A, we move on to Row 2.

Row 2: Option A has an expected payoff of 180, while Option B has an expected payoff of 130 Notice that while the odds within each pair of outcomes are the same, the amount you could win are different. Specifically, Option B is riskier. 
Everyone preferred Option A over Option B in Row 1. In Row 2, if you now prefer Option B, then simply click anywhere in Row 2, and then advance to the next screen. However, if you still prefer Option A in Row 2, then move on to Row 3, and decide which gamble you prefer. Continue to compare the gambles row by row, until you switch from preferring Option A and start to prefer Option B. Click in that row, and then advance the screen.

\begin{tabular}{|c|c|c|c|c|}
\hline & Option A & & Option B & \\
\hline $\begin{array}{c}\text { Row } \\
\#\end{array}$ & Chances & $\begin{array}{r}\text { Expected } \\
\text { payoff }\end{array}$ & Chances & $\begin{array}{r}\text { Expected } \\
\text { payoff }\end{array}$ \\
\hline 1 & $\begin{array}{l}0 / 10 \text { chance of } 225 \text { tokens } 10 / 10 \\
\text { chance of } 175 \text { tokens }\end{array}$ & 175 & $\begin{array}{l}0 / 10 \text { chance of } 400 \text { tokens } 10 / 10 \\
\text { chance of } 100 \text { tokens }\end{array}$ & 100 \\
\hline 2 & $\begin{array}{l}1 / 10 \text { chance of } 225 \text { tokens } 9 / 10 \text { chance } \\
\text { of } 175 \text { tokens }\end{array}$ & 180 & $\begin{array}{l}1 / 10 \text { chance of } 400 \text { tokens } 9 / 10 \\
\text { chance of } 100 \text { tokens }\end{array}$ & 130 \\
\hline 3 & $\begin{array}{l}2 / 10 \text { chance of } 225 \text { tokens } 8 / 10 \text { chance } \\
\text { of } 175 \text { tokens }\end{array}$ & 185 & $\begin{array}{l}2 / 10 \text { chance of } 400 \text { tokens } 8 / 10 \\
\text { chance of } 100 \text { tokens }\end{array}$ & 160 \\
\hline 4 & $\begin{array}{l}3 / 10 \text { chance of } 225 \text { tokens } 7 / 10 \text { chance } \\
\text { of } 175 \text { tokens }\end{array}$ & 190 & $\begin{array}{l}3 / 10 \text { chance of } 400 \text { tokens } 7 / 10 \\
\text { chance of } 100 \text { tokens }\end{array}$ & 190 \\
\hline 5 & $\begin{array}{l}4 / 10 \text { chance of } 225 \text { tokens } 6 / 10 \text { chance } \\
\text { of } 175 \text { tokens }\end{array}$ & 195 & $\begin{array}{l}4 / 10 \text { chance of } 400 \text { tokens } 6 / 10 \\
\text { chance of } 100 \text { tokens }\end{array}$ & 220 \\
\hline 6 & $\begin{array}{l}5 / 10 \text { chance of } 225 \text { tokens } 5 / 10 \text { chance } \\
\text { of } 175 \text { tokens }\end{array}$ & 200 & $\begin{array}{l}5 / 10 \text { chance of } 400 \text { tokens } 5 / 10 \\
\text { chance of } 100 \text { tokens }\end{array}$ & 250 \\
\hline 7 & $\begin{array}{l}6 / 10 \text { chance of } 225 \text { tokens } 4 / 10 \text { chance } \\
\text { of } 175 \text { tokens }\end{array}$ & 205 & $\begin{array}{l}6 / 10 \text { chance of } 400 \text { tokens } 4 / 10 \\
\text { chance of } 100 \text { tokens }\end{array}$ & 280 \\
\hline 8 & $\begin{array}{l}7 / 10 \text { chance of } 225 \text { tokens } 3 / 10 \text { chance } \\
\text { of } 175 \text { tokens }\end{array}$ & 210 & $\begin{array}{l}7 / 10 \text { chance of } 400 \text { tokens } 3 / 10 \\
\text { chance of } 100 \text { tokens }\end{array}$ & 310 \\
\hline 9 & $\begin{array}{l}8 / 10 \text { chance of } 225 \text { tokens } 2 / 10 \text { chance } \\
\text { of } 175 \text { tokens }\end{array}$ & 215 & $\begin{array}{l}8 / 10 \text { chance of } 400 \text { tokens } 2 / 10 \\
\text { chance of } 100 \text { tokens }\end{array}$ & 340 \\
\hline 10 & $\begin{array}{l}9 / 10 \text { chance of } 225 \text { tokens } 1 / 10 \text { chance } \\
\text { of } 175 \text { tokens }\end{array}$ & 220 & $\begin{array}{l}9 / 10 \text { chance of } 400 \text { tokens } 1 / 10 \\
\text { chance of } 100 \text { tokens }\end{array}$ & 370 \\
\hline 11 & $\begin{array}{l}\text { 10/10 chance of } 225 \text { tokens } 0 / 10 \\
\text { chance of } 175 \text { tokens }\end{array}$ & 225 & $\begin{array}{l}10 / 10 \text { chance of } 400 \text { tokens } 0 / 10 \\
\text { chance of } 100 \text { tokens }\end{array}$ & 400 \\
\hline
\end{tabular}

Measure of Ambiguity Aversion - Standard multiple price list instrument developed by Gneezy et al. (2015)

Hypothetical Example: Imagine you are investing a relatively large sum of money from your current assets

Urn A contains 10 total balls: 5 red balls and 5 black balls. Urn B also contains 10 total red and black balls, but you have no idea how many of the 10 balls are red versus black

You start the game by selecting a color: RED or BLACK. For example, let's assume you picked RED. You will then review Row 1 of the table below. Would you prefer to draw a ball from Urn A or Urn B? The urn you choose will have a ball randomly drawn from it. If a red ball is drawn, you win 200 tokens, as indicated in Row 1. If a black ball is drawn, you earn nothing

You know from Row 1 of the table that there are 5 red and 5 black balls in Urn A, so you have a $50 \%$ chance of winning 200 tokens, and the same odds of winning nothing. If you decide to draw a ball from Urn B, you have no idea what your odds are of 
drawing a red ball because while you know there are 10 total red and black balls, you have no idea if there are 3 red and 7 black balls, or 9 red and 1 black ball, etc. All you know is that if you draw a red ball, you will win 10 tokens

While there are no wrong answers, almost everyone prefers Urn A over Urn B in Row 1. Why? Because even if Urn B turns out to have 10 red balls, while you know you will draw a red ball, you will only win 10 tokens. Urn A has only 5 red balls, but if you draw one of them, you get 200 tokens. In this example, Urn A has a $50 \%$ chance of winning 200 tokens, while Urn B has at best an unknown chance to win 10 tokens. So, let's assume you prefer Urn A in Row 1. Now, we consider Row 2

Row 2: Would you rather draw from Urn A where you have a $50 \%$ chance of earning 200 tokens, or draw from Urn B where you do not know the odds, but will earn 180 tokens if you draw a red ball? If you now prefer Urn B, then click somewhere in Row 2, then advance to the next screen. We will draw the ball from Urn B and see if you won. However, if you still prefer Urn A, then go down to Row 3, and repeat the decision. Ultimately, we want you to indicate at which row you would first switch from preferring Urn A to Urn B by clicking anywhere within the row. Do not consider any rows past the first row where you view Urn B as the better option. After selecting your row, advance to the next screen

Please start the game by selecting either the color RED or BLACK now. (Red or Black)

Now indicate at which row you would first switch from preferring Urn A to Urn B by clicking anywhere within the row

\begin{tabular}{lll}
\hline & Urn A (10 Total Balls) & Urn B (10 Total Balls) \\
Row \# & 5 Red Balls; 5 Black Balls & ? Red Balls; ? Black Balls \\
1 & 200 tokens if chosen color; 0 otherwise & 10 tokens if chosen color; 0 otherwise \\
2 & 200 tokens if chosen color; 0 otherwise & 180 tokens if chosen color; 0 otherwise \\
3 & 200 tokens if chosen color; 0 otherwise & 190 tokens if chosen color; 0 otherwise \\
4 & 200 tokens if chosen color; 0 otherwise & 200 tokens if chosen color; 0 otherwise \\
5 & 200 tokens if chosen color; 0 otherwise & 210 tokens if chosen color; 0 otherwise \\
6 & 200 tokens if chosen color; 0 otherwise & 220 tokens if chosen color; 0 otherwise \\
7 & 200 tokens if chosen color; 0 otherwise & 230 tokens if chosen color; 0 otherwise \\
8 & 200 tokens if chosen color; 0 otherwise & 240 tokens if chosen color; 0 otherwise \\
9 & 200 tokens if chosen color; 0 otherwise & 250 tokens if chosen color; 0 otherwise \\
10 & 200 tokens if chosen color; 0 otherwise & 260 tokens if chosen color; 0 otherwise \\
11 & 200 tokens if chosen color; 0 otherwise & 270 tokens if chosen color; 0 otherwise \\
\hline
\end{tabular}

Big Five Personality Questions - (Rammstedt and John 2007)

Instruction: How well do the following statements describe your personality?

I see myself as someone who ...

$\begin{array}{llllll} & \begin{array}{l}\text { Disagree } \\ \text { strongly }\end{array} & \begin{array}{l}\text { Disagree } \\ \text { a little }\end{array} & \begin{array}{l}\text { Neither agree } \\ \text { nor disagree }\end{array} & \begin{array}{l}\text { Agree } \\ \text { a little }\end{array} & \begin{array}{l}\text { Agree } \\ \text { strongly }\end{array} \\ \text { is reserved } & (1) & (2) & (3) & (4) & (5) \\ \text { is generally trusting } & (1) & (2) & (3) & (4) & (5) \\ \text { tends to be lazy } & (1) & (2) & (3) & (4) & (5)\end{array}$




$\begin{array}{llllll}\text { is relaxed, handles stress well } & (1) & (2) & (3) & \text { (4) } & \text { (5) } \\ \text { has few artistic interests } & (1) & (2) & (3) & (4) & (5) \\ \text { is outgoing, sociable } & (1) & (2) & (3) & (4) & (5) \\ \text { tends to find fault with others } & (1) & (2) & (3) & (4) & (5) \\ \text { does a thorough job } & (1) & (2) & (3) & (4) & (5) \\ \text { gets nervous easily } & (1) & (2) & (3) & (4) & (5) \\ \text { has an active imagination } & (1) & (2) & (3) & (4) & (5) \\ \text { is considerate and kind to almost everyone } & (1) & (2) & (3) & (4) & (5)\end{array}$

Financial Literacy Questions - from FINRA Investor Education Foundation

Suppose you had $\$ 100$ in a savings account and the interest rate was $2 \%$ per year. After 5 years, how much do you think you would have in the account if you left the money to grow?
- More than $\$ 102$
- Exactly $\$ 102$
- Less than $\$ 102$
- I do not know

Imagine that the interest rate on your savings account was $1 \%$ per year and inflation was $2 \%$ per year. After 1 year, how much would you be able to buy with the money in this account?
- More than today
- Exactly the same
- Less than today
- I do not know

True or False. "Buying a single company's stock usually provides a safer return than a stock mutual fund."
- True
- False
- I do not know

A 15-year mortgage typically requires higher monthly payments than a 30 -year mortgage but the total interest over the life of the loan will be less.
- True
- False
- I do not know

Suppose you owe $\$ 1,000$ on a loan and the interest rate you are charged is $20 \%$ per year compounded annually. If you didn't pay anything off, at this interest rate, how many years would it take for the amount you owe to double?
- Less than 2 years
- 2 - 4 years
- 5 - 9 years
- More than 10 years
- I do not know

\section{References}

Ackert, L., Charupat, N., Church, B., \& Deaves, R. (2006). An experimental examination of the house money effect in a multi-period setting. Experimental Economics, 9(1), 5-16. 
Armona, L., Fuster, A., \& Zafar, B. (2019). Home price expectations and behavior: Evidence from a randomized information experiment. Review of Economic Studies, 86(4), 1371-1410.

Azrieli, Y., Chambers, C., \& Healy, P. (2018). Incentives in experiments: A theoretical analysis. Journal of Political Economy, 126(4), 1472-1503.

Baillon, A., \& Bleichrodt, H. (2015). Testing ambiguity models through the measurement of probabilities for gains and losses. American Economic Journal: Microeconomics, 7(2), 77-100.

Becker, A., Deckers, T., Dohmen, T., Falk, A., \& Kosse, F. (2012). The relationship between economic preferences and psychological personality measures. Annual Review of Economics, 4(1), 453-478.

Bellemare, C., Kröger, S., \& Van Soest, A. (2008). Measuring inequity aversion in a heterogeneous population using experimental decisions and subjective probabilities. Econometrica, 76(4), 815-839.

Bianchi, M., \& Tallon, J. (2018). Ambiguity preferences and portfolio choices: Evidence from the field. Management Science, 65(4), 1486-1501.

Borghans, L., Duckworth, A. L., Heckman, J. J., \& Ter Weel, B. (2008). The economics and psychology of personality traits. Journal of Human Resources, 43(4), 972-1059.

Bossaerts, P., Ghirardato, P., Guarnaschelli, S., \& Zame, W. (2010). Ambiguity in asset markets: Theory and experiment. Review of Financial Studies, 23(4), 1325-1359.

Charness, G., Gneezy, U., \& Imas, A. (2013). Experimental methods: Eliciting risk preferences. Journal of Economic Behavior and Organization, 87(C), 43-51.

Chen, C., \& Chang, C. (2019). How big are the ambiguity-based premiums on mortgage insurances? Journal of Real Estate Finance and Economics, 58(1), 133-157.

Collard, F., Mukerji, S., Sheppard, K., \& Tallon, J. (2018). Ambiguity and the historical equity premium. Quantitative Economics, 9(2), 945-993.

Costa, P., \& McCrae, R. (1992). The five-factor model of personality and its relevance to personality disorders. Journal of Personality Disorders, 6(4), 343-359.

Dimmock, S., Kouwenberg, R., \& Wakker, P. (2015). Ambiguity attitudes in a large representative sample. Management Science, 62(5), 1363-1380.

Dimmock, S. G., Kouwenberg, R., Mitchell, O. S., \& Peijnenburg, K. (2016). Ambiguity aversion and household portfolio choice puzzles: Empirical evidence. Journal of Financial Economics, 119(3), 559577.

Dohmen, T., Falk, A., Huffman, D., \& Sunde, U. (2010). Are risk aversion and impatience related to cognitive ability? American Economic Review, 100(3), 1238-1260.

Dow, J., \& Werlang, S. (1992). Uncertainty aversion, risk aversion, and the optimal choice of portfolio. Econometrica, 60(1), 197-204.

Easley, D., \& O'Hara, M. (2009). Ambiguity and nonparticipation: The role of regulation. Review of Financial Studies, 22(5), 1817-1843.

Elabed, G., \& Carter, M. (2015). Compound-risk aversion, ambiguity and the willingness to pay for microinsurance. Journal of Economic Behavior \& Organization, 118(C), 150-166.

Ellsberg, D. (1961). Risk, ambiguity, and the savage axioms. Quarterly Journal of Economics, 75(4), 643669.

Ghirardato, P., Maccheroni, F., \& Marinacci, M. (2004). Differentiating ambiguity and ambiguity attitude. Journal of Economic Theory, 118(2), 133-173.

Gneezy, U., List, J., \& Wu, G. (2006). The uncertainty effect: When a risky prospect is valued less than its worst possible outcome. Quarterly Journal of Economics, 121(4), 1283-1309.

Gneezy, U., Imas, A., \& List, J. (2015). Estimating individual ambiguity aversion: A simple approach. NBER working paper no. 20982.

Gollier, C. (2011). Portfolio choices and asset prices: The comparative statics of ambiguity aversion. Review of Economic Studies, 78(4), 1329-1344.

Golman, R., \& Loewenstein, G. (2018). Information gaps: A theory of preferences regarding the presence and absence of information. Decision, 5(3), 143-164.

Golman, R., Gurney, N., \& Loewenstein, G. (2021). Information gaps for risk and ambiguity. Psychological Review, 128(1), 86-103. https://doi.org/10.1037/rev0000252.

Guiso, L., Sapienza, P., \& Zingales, L. (2008). Trusting the stock market. Journal of Finance, 63(6), 25572600.

Halevy, Y. (2007). Ellsberg revisited: An experimental study. Econometrica, 75(2), 503-536.

Harrison, D. M., Luchtenberg, K. F., Seiler, M. J. (2021). Improving mortgage default collection efforts by employing the decoy effect. Journal of Real Estate Finance and Economics. (forthcoming).

Holt, C., \& Laury, S. (2002). Risk aversion and incentive effects. American Economic Review, 92 (5), 1644 1655 . 
Izhakian, Y., \& Yermack, D. (2017). Risk, ambiguity, and the exercise of employee stock options. Journal of Financial Economics, 124(1), 65-85.

Ju, N., \& Miao, J. (2012). Ambiguity, learning, and asset returns. Econometrica, 80(2), 559-591.

Kahneman, D., \& Tversky, A. (1979). Prospect theory: An analysis of decision under risk. Econometrica, 47, 263-291.

Kaplan, S., Klebanov, M., \& Sorensen, M. (2012). Which CEO characteristics and abilities matter? Journal of Finance, 67(3), 973-1007.

Kocher, M., Lahno, A., \& Trautmann, S. (2018). Ambiguity aversion is not universal. European Economic Review, 101(C), 268-283.

Lo, A., Repin, D., \& Steenbarger, B. (2005). Fear and greed in financial markets: A clinical study of daytraders. American Economic Review, 95(2), 352-359.

Loewenstein, G. (1994). The psychology of curiosity: A review and reinterpretation. Psychological Bulletin, 116(1), 75-98.

Lusardi, A., \& Mitchell, O. (2014). The economic importance of financial literacy: Theory and evidence. Journal of Economic Literature, 52(1), 5-44.

Maenhout, P. (2004). Robust portfolio rules and asset pricing. Review of Financial Studies, 17(4), 951-983.

Peijnenburg, K. (2018). Life-cycle asset allocation with ambiguity aversion and learning. Journal of Financial and Quantitative Analysis, 53(5), 1963-1994.

Peterson, R. (2007). Affect and financial decision-making: How neuroscience can inform market participants. Journal of Behavioral Finance, 8(2), 70-78.

Puri, M., \& Robinson, D. (2007). Optimism and economic choice. Journal of Financial Economics, 86(1), 71-99.

Rammstedt, B., \& John, O. (2007). Measuring personality in one minute or less: A 10-item short version of the big five inventory in English and German. Journal of Research in Personality, 41(1), 203-212.

Rustichini, A., DeYoung, C., Anderson, J., \& Burks, S. (2016). Toward the integration of personality theory and decision theory in explaining economic behavior: An experimental investigation. Journal of Behavioral and Experimental Economics, 64(C), 122-137.

Thaler, R., \& Johnson, E. (1990). Gambling with the house money and trying to break even: The effects of prior outcomes on risky choice. Management Science, 36(6), 643-660.

Van Rooij, M., Lusardi, A., \& Alessie, R. (2011). Financial literacy and stock market participation. Journal of Financial Economics, 101(2), 449-472.

Weber, M., \& Zuchel, H. (2005). How do prior outcomes affect risk attitude? Comparing escalation of commitment and the house-money effect. Decision Analysis, 2(1), 30-43.

Zahirovic-Herbert, V., Gibler, K. M., \& Chatterjee S. (2016). Financial literacy, risky mortgages, and delinquency in the US during the financial crisis. International Journal of Housing Markets and Analysis, 9(2), 164-189.

Publisher's Note Springer Nature remains neutral with regard to jurisdictional claims in published maps and institutional affiliations. 